\title{
АГРОТЕХНИЧЕСКОЕ ОБЕСПЕЧЕНИЕ ВЕДЕНИЯ МАТОЧНЫХ НАСАЖДЕНИЙ МАЛИНЫ КРАСНОЙ НА ОСНОВЕ АДАПТИРОВАННЫХ ЭКОЛОГИЧЕСКИ БЕЗОПАСНЫХ ПРИЁМОВ
}

А.Н. Перекопкий, канд. техн. наук, доцент

Контактная информация (e-mail): aperekopskii@mail.ru

В.А. Юнин, канд. техн. наук

Контактная информация (e-mail): vim_iaep@mail.ru

\section{А.В. Зыков}

Контактная информация (e-mail): zav35@list.ru

К.И. Егорова, аспирант

Контактная информация (e-mail): unknown_06@list.ru

Институт агроинженерных и экологических проблем сельскохозяйственного производства филиал ФГБНУ ФНАЦ ВИМ (г. СПб, РФ)

ВВЕДЕНИЕ. Малина является одной из ведущих ягодных культур России. Ценные качества ягод малины обеспечили ей широкую популярность и распространение в стране. В основном малина представлена в насаждениях населения. Развитие культуры на промышленной основе сдерживается отсутствием отечественной ягодоуборочной техники. Ягодоуборочные комбайны «Karen» и «Natalia», выпускаемые немецкой фирмой "WEREMCZUK FMR" для сбора ягод малины, применяются в садоводстве европейских государств, но в России эти комбайны - не используются [1].

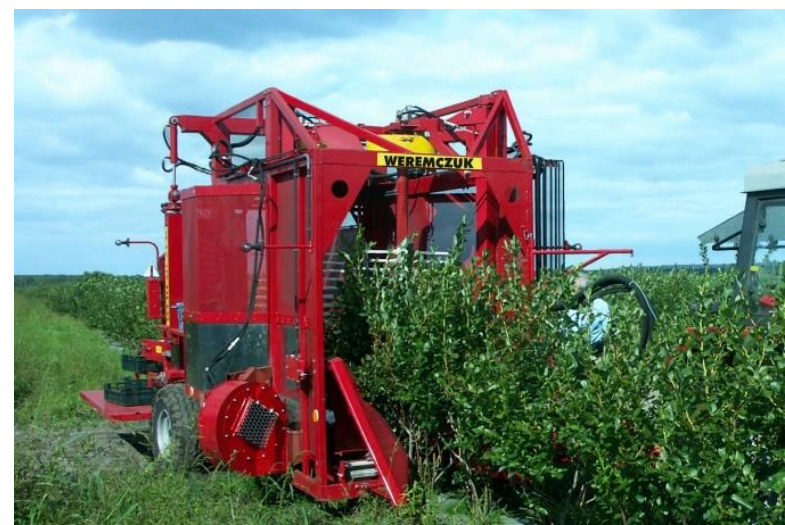

a) Karen

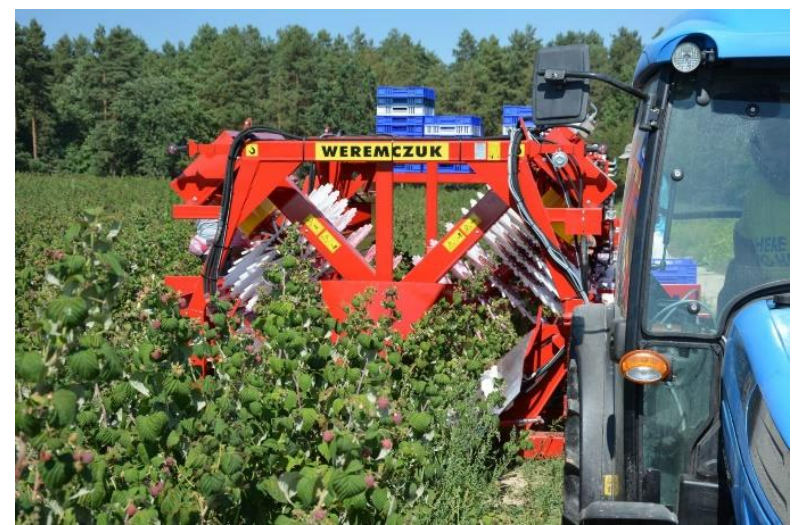

б) Natalia-V

a - комбайн «Karen» для уборки малины и голубики;

б - комбайн «Natalia-V» для уборки ремонтантной малины

Рис. 1 Прицепные комбайны для уборки малины фирмы "WEREMCZUK FMR"

В настоящее время в Северо-Западном регионе и в Центральном районе нет специализированных питомников малины. Выращивание саженцев ведется в небольших объёмах в частных питомниках. Население использует отпрыски с продуктивных насаждений, что ведёт к засорению насаждений малины сортосмесями и сеянцами от свободного опыления; способствует распространению вирусных и грибных заболеваний. Товарные плантации малины не являются источником качественного посадочного материала.

В технологическом аспекте в систему производства саженцев малины входит рациональное размещение маточных растений на площади питомника, система машин, состав которой определяется способом размножения малины. Спецификой выращивания саженцев малины, свободных от вредителей и болезней, является применение системы защитных мероприятий от вредоносных насекомых и возбудителей болезней.

В Северо-Западной зоне РФ проводились исследования по выращиванию здорового посадочного материала малины и функционировали специальные маточники (ИАЭП филиал ФГБНУ ФНАЦ ВИМ Ленинградская ПООС) [2, 3]. 
Анализ данных исследований наших коллег и результатов работы промышленных питомников дает возможность выбора наиболее рациональной формы ведения питомника малины. В соответствии с требованиями современной методологии развития садоводства предпочтителен питомник, обеспечивающий условия механизации рабочих процессов и использование приёмов его ведения, снижающих антропогенную нагрузку на окружающую среду [4-6].

Одним из вариантов такой технологии является ведение питомника с 2-3-летним продуктивным периодом и ведением дерново-перегнойной системы содержания почвы в междурядьях сада вместо постоянного парования почвы. Дерново-перегнойная система осуществляется путём постоянного задернения почвы многолетними низовыми злаковыми травами и многократного скашивания их (4-6 раз за сезон) с оставлением скошенной и измельченной травы на месте. Этот способ содержания почвы рассматривается как средообразующий фактор, снижающий антропогенную нагрузку на окружающую среду за счёт сокращения машинных рабочих операций и удешевления производства саженцев на $25 \%$.

Цель работы - анализ литературных источников по ведению маточных насаждений малины красной на основе адаптированных экологически безопасных приёмов

ОБЪЕКТ И МЕТОДИКА. Потребность в посадочном материале определяется, прежде всего, объёмом промышленного производства ягод малины. Как отмечается Ассоциацией производителей плодов, ягод и посадочного материала, промышленное выращивание малины расширяется по всему миру. Приблизительная площадь возделывания составляет 71250 гектаров, на долю малины приходится около 38 \% мирового сбора ягод этой культуры [6].

Основными производителями ягод малины являются страны Европы - Сербия, Черногория, Польша, Германия, Венгрия, Франция, Англия и др. Активно развивается эта отрасль садоводства в Чили, Мексике, Китае, Аргентине и Сербии. Положено начало промышленного выращивания малины в Испании, Италии, в Северной Африке. Увеличению производства ягод малины способствует создание новых сортов и использование ягодоуборочной техники. Расширение объёма производства продукции происходит также в странах с дешёвой рабочей силой.

В Российской Федерации, занимающей ведущее место в выращивании ягод малины, основными производителями саженцев малины, как и во всех странах Восточной Европы, являются небольшие хозяйства. В Западной Европе и Северной Америке образованы крупные компании, которые способны конкурировать на рынке.

Ведение специальных маточников малины имеет исключительно важное значение в развитии этой культуры. Известно, что в 50-х годах прошлого столетия происходило сокращение площади, занятой малиной из-за сильного поражения растений различными болезнями. Этот процесс был приостановлен путём выращивания саженцев малины в специализированных питомниках, замены легкопоражаемых сортов относительно устойчивыми, а также планомерной борьбы с переносчиками инфекций.

В России были разработаны зональные системы производства саженцев малины для обеспечения потребности в посадочном материале хозяйств и населения такими научными учреждениями, как РГАУ-МСХА им. К.А. Тимирязева, ФГБНУ ФНЦ Садоводства, ИАЭП филиал ФГБНУ ФНАЦ ВИМ - Ленинградская ПООС, Отдел "НИИСС имени М.А. Лисавенко" ФГБНУ ФАНЦА. Функционировали промышленные питомники малины в Тульской, Рязанской, Вологодской, Кировской, Брянской, Курганской и Челябинской областях. Производство саженцев малины достигало значительных объёмов.

Распространение здорового посадочного материала повысило качество товарных насаждений, но роста площади под малиной не произошло. Причины такого положения в ягодоводстве заключались в отсутствии целевого задания на производство ягодной продукции, освоения современных способов переработки ягод, эффективного ценообразования. В настоящее время сдерживающими развития ягодоводства являются те же факторы.

РЕЗУЛЬТАТЫ ИССЛЕДОВАНИЙ. Одной из основных задач специальных маточ- 
ников является размножение высокотоварных перспективных сортов, устойчивых к патогенам. По типу плодоношения малина представлена тремя типами.

Традиционные сорта, плодоносящие на двухлетних стеблях (на побегах прошлого года). Сорта отличаются неприхотливостью к почвенно-климатическим условиям, ежегодно дают большое количество отпрысков. К недостаткам сортов этого типа относятся: слабая зимостойкость, недостаточная урожайность, плодоношение один раз в сезон.

Ремонтантные сорта. Сорта, плодоносящие длительное время. Первый урожай формируется на побегах прошлого года в начале-середине июля, второй урожай - созревает на концах побегов в конце августа-начале сентября. Продолжительность осеннего сбора ягод может длиться до ноября, до заморозков. Ремонтантные сорта отличаются высокой урожайностью, обеспечивают длительный срок потребления ягод. По вкусу ягоды ремонтантных сортов уступают многим традиционным сортам.

Фотонейтральные сорта. К этому типу сортов относятся ремонтантные сорта, плодоносящие на однолетних побегах. Образующиеся весной побеги к середине лета зацветают и плодоносят. Отплодоносившие побеги вырезают или скашивают, вывозят за пределы питомника и сжигают. У многих фотонейтральных сортов ягоды крупнее и урожайность выше, чем у традиционных сортов. Эти сорта требовательны к теплу, в регионе не имеют широкого распространения, так как не создано ещё достаточно адаптивных сортов для условий СевероЗапада.

Наиболее значимая селекция малины красной ведется в ФГБНУ ВСТИСП - Кокинском опорном пункте ВСТИСП (Брянская область) и в Свердловской селекционной станции садоводства - структурное подразделение ФГБНУ УрФАНИЦ УрО РАН (г. Екатеринбург) $[7,8]$.

В настоящее время селекция рода Rubus ведется более, чем в 20 странах мира, включая исследования по трём типам сортов малины. В ряде стран программы селекции малины свернуты (штат Минисота, НИИ садоводства Новой Зеландии), в то же время наблюдается тенденция привлечение в селекцию малины частных инвестиций. К таким организациям относятся крупные транснациональные компании DSA, Frutis Berry Grower, Redbridg/Redeva.

Имеется положительный опыт частной селекции в Украине, где в фермерском хозяйстве Брусвяна выведены высокопродуктивные сорта: Брусиловская, Брусвяна, Примара, Ярославна [9].

В странах Балтии созданы зимо- и морозостойкие сорта, устойчивые к возвратным весенним заморозкам. В Латвийском Государственном институте плодоводства создан ряд сортов, адаптированных к местным условиям: Ina, Lina, Viktorija. В качестве источника высокой адаптивности в Исследовательском центре садоводства Эстонии - Полли используется российский сорт Новость Кузьмина. В Литве предпочтение отданы фотонейтральным сортам. Выделены перспективные формы, плодоносящие на однолетних побегах, с ранним сроком созревания ягод: Ru-1, Ru-2.

На Польской опытной станции плодоводства в Brzezna выведены сорта традиционные и фотонейтральные: Polana, Polka, Porana Rosa, Pokusa. Наибольший коммерческий успех в Европе имеет сорт Polka, подходящий для промышленного возделывания.

Одним из старейших и наиболее результативных научных учреждений, занимающихся созданием новых сортов малины - Ист-Маллингская опытная станция (Англия), выведена серия сортов Glen, получившая мировое признание. Среди новых сортов первые в мире бесшипные сорта Glen Doll, Glen Fyne, пригодные для механизированной уборки урожая. C 2003 г. на Ист-Моллинге особое значение придается созданию фотонейтральных сортов [10].

В Северной Америке селекция малины ведется в штате Орегон, в Университетах штатов Мэри-Ленд и Вашингтон; в Тихоокеанском НИИ Центре сельского хозяйства и продовольствия Канады. В этих учреждениях в селекции используются адаптивные особенности 58 дикорастущих видов.

Существует несколько способов выращивания саженцев малины в специальных маточниках. К основным способам относятся следующие: 
Размножение одревесневшими отпрысками. Саженец состоит из 1-2 стеблей, корневища - с 1-2 почками, из которых в следующем вегетационном периоде вырастают побеги замещения; 3-4 придаточных корней длиною 10-20 см, с почками и без почек, с мочковатыми корнями и без них.

Размножение зелёными отпрысками. Зелёный отпрыск - молодое растение с облиственным стеблем высотою 20-25 см, которое имеет корневище с молодыми придаточными корнями и небольшую часть материнского корня.

Размножение корневыми черенками. Корневой черенок - отрезок корня длиной 8-12 см, диаметром не менее 1 мм. С почками на нём, или без почек.

Размножение малины зелёными черенками и зелёными ростками в промышленных питомниках не использовалось. Основным способом в промышленных условиях является размножение малины одревесневшими отпрысками [11].

В результате исследований, проведенных в ФГБНУ ФНЦ Садоводства, рекомендована блочная схема посадки маточных растений в питомнике $(2,5+0,7)$ х $(2,5+0,7)$ м, обеспечивающая выход 4000 саженцев с 1 га. Каждый блок представляет собою квадрат 0,7х0,7 м с междурядием 2,5 метра. Разреженная посадка обеспечивает хорошее проветривание основания куста, уменьшает влажность воздуха в предземном слое, что снижает развитие грибных и мелкоплазменных болезней.

Другой способ размещения растений - рядовая схема посадки - $(2,5-3,0) x(0,5-0,7)$ м. Такая схема размещения обеспечивает большой выход саженцев и проще для проведения закладки маточника.

При наличии достаточного количества посадочного материала экономически оправдана схема посадки 0,9 х 05 м; через 8-2 рядов оставляются дороги шириною 2,7 м.

Отпрыски малины растут вдоль ряда, образуя сплошную полосу, ширина которой зависит от схемы посадки в питомнике. При однострочной посадке ширина полосы составляет 0,5-0,7 м; при двухстрочной - до 1,5 м. Ширина полосы более 0,9 м усложняет уход за растениями, увеличивает опасность распространения грибных заболеваний [11].

Наиболее детально исследовалось влияние ширины полосы на количество и качество саженцев малины ЛПООС. Проводились исследования выращивания саженцев малины в течение 4-х ротаций, с 1973 по 1982 гг. [12]. Исследовались схемы размещения маточных растений на площади питомника: 2,0х0,75 м; 2,0x1,0 м; 2,0x1,4 м; 3,0x0,5 м; 2,5х0,5 м; 2,5х0,75 м; 2,5х1,0 м. Результаты исследований показали чёткую сортовую зависимость по продуктивности и устойчивости растений к пурпуровой пятнистости. Других возбудителей болезней в питомнике не было. Установлена существенность зависимости качества саженцев от схем размещения и длительности эксплуатации маточника. Данные объёма корневой системы саженцев показали обратную зависимость от продуктивности маточника: чем выше была продуктивность маточника, тем меньшего объёма формировалась корневая система саженца.

Для условий Северо-Западного региона рациональна ширина полосы в питомнике 1,2 м, при междурядиях 2,5 м. Такая полоса - лента обеспечивает выход саженцев до 60 тыс. с 1 га. Расширение полосы и повышение выхода саженцев более 60 тыс. создаёт загущение в полосе и увеличивает количество нестандартных саженцев. В два первых года эксплуатации маточника достигалась максимальная его продуктивность. На третий год - выход посадочного материала резко снижался.

Осуществление системы защитных мер от вредителей и болезней в маточнике малины - одно из главных условий выращивания здоровых саженцев. При планировании применения средств борьбы с вредоносными насекомыми и болезнями растений учитывается постоянное обновление пестицидов и фунгицидов.

В условиях Северо-Западного региона малину поражают болезни: антракноз, септориоз, ржавчина, пятнистости, корневой и стеблевой рак; встречаются вирусные заболевания: курчавость листьев, кольцевая пятнистость, жёлтая сетчатость. У вирусов имеются свои переносчики: тля и почвенные нематоды.

К наиболее вредоносным насекомым малины относятся: малинная стеблевая и побе- 
говая галлица, малинная стеблевая муха, тля, паутинный клещ. В результате профилактических и истребительных мер защиты растений не было выявлено антракноза и стеблевого комарика. Установлена высокая эффективность фундозола 0,5 \%-ного против антракноза и пурпуровой пятнистости. Поражение отпрысков пурпуровой пятнистостью увеличивался на второй год эксплуатации маточника в результате загущения растений в полосе при выходе саженцев свыше 60 тыс. шт. с 1 га. При выходе отпрысков 90-120 тыс. шт. с 1 га. зараженность побегов достигала $90 \%$, а развитие болезни - $24 \%$. На третий год функционирования маточника - зараженность побегов и степень развития болезни снижается.

Поражение пурпуровой пятнистостью, в значительной степени, определяется устойчивостью сорта. Полевой устойчивостью к пурпуровой пятнистости характеризуются сорта малины: Метеор, Новость Кузьмина, Беглянка, Блестящая, Коралловая; в средней степени поражаются этой болезней сорта: Бальзам, Ранняя Заря, Соколёнок, Бригантина.

Таблица 1. Система машин, для ведения маточного питомника малины [12, 13]

\begin{tabular}{|c|c|c|}
\hline \multicolumn{3}{|l|}{ Закладка маточника } \\
\hline Дискование почвы в 2 следа & \multirow{9}{*}{$\begin{array}{l}\text { (Апрель- май или } \\
\text { август-сентябрь) }\end{array}$} & БДТ-3 \\
\hline Внесение органических удобрений & & POУ-6A \\
\hline Внесение минеральных удобрений & & МВУ-5 \\
\hline Вспашка & & ПЛН-3-35 \\
\hline Дискование, культивация & & БДСТ-3,5А \\
\hline Посадка саженцев малины & & $\begin{array}{l}\text { S243; СПУ-1; } \\
\text { МПС-1 }\end{array}$ \\
\hline Подвоз воды и полив & & ОПМ-5,0 \\
\hline $\begin{array}{l}\text { Культивация междурядий широкозахватным пропашным высо- } \\
\text { коклиренсным культиватором }\end{array}$ & & КРH-4,2 \\
\hline Опрыскивание против вредителей и болезней & & OBC-600C \\
\hline \multicolumn{3}{|c|}{ Маточник первого и второго года эксплуатации } \\
\hline Опрыскивание против вредителей и болезней 4-5-кратное & (апрель-август) & OBC-600C \\
\hline Культивация междурядий 5-7 кратная & (май-сентябрь) & КРН-4,2, \\
\hline Внесение азотных удобрений & (май) & MBУ-5 \\
\hline Скашивание стеблей на высоте 30-40 см. & (сентябрь) & KPC-2 \\
\hline Подрезка корней скобой & (середина сентября) & КНУ-1,2 \\
\hline Мульчирование полос & & $\begin{array}{l}\text { МОЗ-2; КИ-2,0; } \\
\text { КСМ-2,5 }\end{array}$ \\
\hline
\end{tabular}

Сортировка саженцев по товарным сортам проводится на основании технических требований к посадочному материалу малины [14].

ЗАКЛЮЧЕНИЕ. В мировой практике садоводства складывается тенденция к расширению производства ягод малины в связи с распространением новых сортов, устойчивых к вредителям и болезням с высокими качествами ягод. Существенным фактором является использование современной техники по уборке урожая.

В России, являющейся одной из ведущих стран по производству ягод малины, источником производства ягод является население страны и частные хозяйства.

Непременным условием успешного производства ягод является обеспечение закладок здоровым чистосортным посадочным материалом.

Заготовка посадочного материала в товарных насаждениях ведёт к засорению сортосмесью и сеянцами от свободного опыления, распространению болезней и вредителей во вновь посаженных ягодниках.

Одной из задач специальных маточников является решение проблемы сортообновления. В настоящее время определилась тенденция к освоению новых типов малины - ремонтантной и фотонейтральной.

В систему производства ведения специальных маточников малины входит рациональное размещение маточных растений на площади питомника, система защитных мер против вредителей и болезней малины.

В условиях Северо-Западного региона основными возбудителями болезней малины 
являются антракноз, септориоз, ржавчина. Пурпуровая пятнистость, корневой и стеблевой рак; вредоносными насекомыми: побеговая и стеблевая галлица, тля, паутинный клещ.

Оценка приемлемости схемы посадки маточных растений в питомнике должна строиться на предварительном расчёте выхода саженцев с единицы площади. В условиях региона подходящей схемой является та, которая обеспечивает выход отпрысков не более 60 тыс. шт. с 1га. (ширина ленты - не более 1,2 м, междурядий - 2,5 м). Ширина междурядия должна соответствовать технике, применяемой в питомнике.

\section{Литература}

1. Машины для сбора малины// Официальный сайт компании «Weremczukagro». [Электронный pecypc]. Режим доступа URL: https://weremczukagro.com/ru/kategoria-produkty/zbior-malina/. (Дата обращения 05.07.2021 г.).

2. Барыльник К.Г. Регионально-адаптивный способ производства посадочного материала малины// Технологии и технические средства механизированного производства продукции растениеводства и животноводства, 2017. - № 91. - С. 104-112.

3. Барыльник К.Г. Ремонтантная малина - перспективы освоения культуры на Северо-Западе России// В сборнике: Сельское хозяйство - драйвер российской экономики. (Для обсуждения и выработки решений). Оргкомитет международной агропромышленной выставки - ярмарки "Агрорусь-2016", 2016. - С. 296.

4. Федоренко В.Ф., Мишуров Н.П., Кондратьева О.В. [и др.]. Анализ состояния и перспективные направления развития питомниководства и садоводства: Науч. аналит. обзор. - М.: ФГБНУ «Росинформагротех», 2019. $-88 \mathrm{c}$.

5. Перекопкий А.Н., Юнин В.А., Зыков А.В. [и др.]. Методология построения зонально-адаптивной машинной технологии производства плодов и ягод с минимальным антропогенным риском для качества продукции и окружающей среды// Известия Международной академии аграрного образования, 2021 - № 53. - С. 14-17.

6. Егорова К.И. Оценка сортов смородины черной на пригодность в комбайновой уборке// Аграрный научный журнал, 2021. - № 7. - С. 35-39

7. Дескриптор генетической биоресурсной коллекции растений ФГБНУ ВСТИСП (плодовые, ягодные, редкие ягодные и цветочно-декоративные культуры). - М., 2018. - 90 с.

8. Невоструева Е.Ю., Карпухин М.Ю., Тимашкова А.Г. Сравнительная оценка сортов и отборных форм малины в условиях Среднего Урала// Коняевские чтения: Сб. научных трудов VII Международной научнопрактической конференции (20 декабря 2019 г.). - Екатеринбург: Уральский ГАУ, 2020. - С. 145-148.

9. Евдокименко С.Н., Кулагина В.Л., Якуб И.А. Современные тенденции производства и селекции малины// Плодоводство и ягодоводство в России, 2012. - Т. 31. - № 1. - С. 148-156.

10. Sargent DJ, Fernández-Fernández F, Rys A, Knight VH, Simpson DW, Tobutt KR. (2007). Mapping of A1 conferring resistance to the aphid Amphorophora idaei and dw (dwarfing habit) in red raspberry (Rubus idaeus L.) using AFLP and Microsatellite markers. BMC Plant Biology 7. 15.

11. Ярославцев Е. И. Малина. - М.: ВО Агропромиздат. 1987. - С. 62-64.

12. Иванова К. И., Копытова Ф. И. Продуктивность и устойчивость к вредителям и болезням маточников малины в зависимости от схем посадки. Сб. науч. тр. НИПТИМЭСХ НЗ РСФСР Повышение продуктивности садов и ягодников в Северо-Западном районе Нечерноземья. - Л., 1984. - С. 3-9.

13. Филиппов Р.А. Смирнов И.Г. Инновационный комплекс машин для садоводства и виноградарства// Таврический вестник аграрной науки, 2017. - № 2 (10). - С. 161-174.

14. Гордеев Б.С., Хандриков В.А., Грубов К.А. Механизация работ в плодовых, ягодных и лесных питомниках: Учебное пособие/ Федеральное гос. бюджетное образов. учреждение высшего проф. образов. «Пермская гос. с.-х. акад. им. акад. Д.Н. Прянишникова». - Пермь: ИПЦ «ПрокростЪ», 2015. - 128 с.

15. Технология получения оздоровительного от вирусов посадочного материала плодовых и ягодных культур: метод. указания. - М.: ФГБНУ «Росинформагротех», 2013. - 92 с. 